\title{
GAMBARAN PENGGUNAAN SEMEN IONOMER KACA SEBAGAI BAHAN TUMPATAN DI RUMAH SAKIT ROBERT WOLTER MONGISIDI MANADO TAHUN 2011-2013
}

\author{
${ }^{1}$ Bonie Tulaka \\ ${ }^{2}$ Dinar A. Wicaksono \\ ${ }^{2}$ Ellen Tumewu
${ }^{1}$ Kandidat Skripsi Program Studi Kedokteran Gigi Fakultas Kedokteran Universitas Sam Ratulangi Manado
${ }^{2}$ Program Studi Kedokteran Gigi Fakultas Kedokteran Universitas Sam Ratulangi
Email: boni.tulaka@gmail.com

\begin{abstract}
Dental caries is still problem among other oral diseases, one of the overcame by restorative. The restorative materials are most frequently used in RS. RW. Mongisidi Manado is glass ionomer cement . The purpose of this research is to know the description of the use of the glass ionomer cement as an ingredient in dental clinic restorative RS. R W. Mongisidi Manado in 2011-2013. This research is descriptive research, the data obtained with the patient's medical record which do restorative throughout the years 2011-2013. The data retrieval is done by the method of the total sample, as 769. The result of this research shows categories sex, male more often done restorative with 394 (51.3\%), patients with adult age category more often do restorative with 609 (79,2\%). The teeth on the anterior portion is more often performed than in the posterior part of the restorative.
\end{abstract}

Keywords: restorative materials, glass ionomer cement

\begin{abstract}
Abstrak: Karies gigi masih merupakan masalah di antara penyakit gigi dan mulut lainnya, salah satu cara mengatasinya yaitu dengan melakukan penumpatan. Bahan tumpatan yang paling sering digunakan di RS. RW. Mongisidi Manado ialah semen ionomer kaca. Tujuan penelitian ini untuk mengetahui gambaran penggunaan semen ionomer kaca sebagai bahan tumpatan di poliklinik gigi RS R.W Mongisidi Manado pada tahun 2011-2013. Penelitian ini merupakan penelitian deskriptif, data diambil dari rekam medis pasien yang telah melakukan penumpatan sepanjang tahun 2011-2013. Pengambilan data dilakukan dengan metode total sampling, didapatkan sepanjang tahun 2011-2013 sebanyak 769.Hasil dari penelitian sepanjang tahun 2011-2013 menunjukkan kategori jenis kelamin, laki-laki lebih sering dilakukan penumpatan dengan 394 (51,3\%), pasien dengan kategori usia dewasa lebih sering melakukan penumpatan dengan 609 (79,2\%). Gigi pada bagian anterior lebih sering dilakukan penumpatan dibandingkan pada bagian posterior.
\end{abstract}

Kata kunci: bahan tumpatan, semen ionomer kaca.

Penyakit karies gigi masih merupakan masalah di antara penyakit gigi dan mulut lainnya. Hampir seluruh penduduk di dunia pernah mengalami karies gigi. Karies gigi adalah penyakit jaringan gigi yang ditandai dengan kerusakan jaringan, dimulai dari permukaan gigi meluas kearah pulpa. Karies ditandai dengan adanya demineralisasi jaringan keras gigi yang kemudian diikuti oleh kerusakan bahan organik. ${ }^{1,2}$

Salah satu cara dalam menanggulangi karies gigi yaitu dengan cara melakukan penumpatan pada gigi yang terkena karies dengan menggunakan bahan restorasi. Tumpatan gigi merupakan suatu perawatan gigi untuk memperbaiki kerusakan gigi 
dengan cara membuang jaringan karies dan meletakan bahan restorasi pada gigi yang mengalami kerusakan. Tindakan perawatan menggunakan bahan tumpatan lebih efektif dibandingkan dengan pencabutan karena pertimbangan estetika dan fungsional.

Seiring dengan perkembangan zaman, bahan tumpatan gigi mengalami kemajuan dari tahun ke tahun. Hal ini membuat pasien dan dokter gigi memiliki berbagai pilihan macam tumpat dalam menumpat gigi yang rusak akibat karies. Jenis yang paling sering digunakan dalam menumpat gigi pada saat ini ialah semen ionomer kaca, amalgam dan resin komposit.

Bahan restorasi gigi harus dipilih dengan cermat dan tepat sesuai dengan indikasinya. Sifat adhesi bahan tumpatan terhadap permukaan gigi merupakan faktor penting yang harus diperhatikan. Seiring dengan perkembangan zaman, segi estetik dari bahan restorasi semakin diperhatikan, dimana bahan tumpatan tersebut menyerupai warna gigi asli. Semen Ionomer Kaca (SIK) merupakan salah satu bahan restorasi yang dibuat untuk memenuhi tujuan tersebut. ${ }^{3,4}$

SIK merupakan bahan tumpat yang mengandung fluor, dapat melepaskan ion fluor dalam jangka panjang sehingga berfungsi sebagai tempat penyimpanan fluor, serta berikatan dengan dentin dan email secara kimiawi melalui mekanisme pertukaran ion. Keuntungan dari bahan restorasi ini yaitu perlekatan ionik permanen terhadap struktur gigi dan kapasitas untuk melepaskan fluorida, memiliki biokompabilitas yang baik terhadap jaringan gigi, solubilitas rendah, anti karies, perubahan dimensi kecil dan tahan terhadap fraktur. Dibalik berbagai keuntungan yang dimiliki oleh SIK terdapat juga beberapa kekurangan yaitu tidak dapat menerima tekanan kunyah yang besar, mudah abrasi dan erosi dan translusent-nya lebih rendah. ${ }^{1,3,5}$

Penggunaan bahan tumpatan dalam aplikasi klinis merupakan salah satu tindakan perawatan yang ada di poliklinik gigi Rumah Sakit Robert Wolter Mongisidi (RS R.W Mongisidi) Manado. RS R.W Mongisidi Manado memiliki poliklinik gigi dengan fasilitas yang cukup menunjang untuk melakukan perawatan gigi dan mulut. Penelitian mengenai SIK di poliklinik gigi RS R.W Mongisidi Manado belum pernah dilakukan hingga saat ini. Berdasarkan latar belakang yang telah diuraikan peneliti tertarik untuk melakukan penelitian mengenai gambaran penggunaan bahan tumpatan SIK di RS R.W Mongisidi Manado pada tahun 2011-2013.

\section{BAHAN DAN METODE}

Penelitian ini merupakan penelitian deskriptif dengan pendekatan retrospektif. Pengambilan sampel pada penelitian ini dengan menggunakan metode total sampling, yaitu mengambil semua data rekam medis pasien yang menggunakan bahan tumpatan SIK di RS R.W. Mongisidi Manado pada tahun 2011 hingga 2013 yaitu sebanyak 769 sampel.Variabel penelitian ini terdiri dari tahun penumpatan, jenis kelamin, usia dan regio gigi.

\section{HASIL PENELITIAN}

Data hasil penelitian menunjukkan Jumlah rekam medis yang digunakan dalam penelitian ini berjumlah 769 rekam medis tahun 2011 hingga 2013. Diagram 1 berikut ini berisi distribusi data rekam medis yang digunakan dalam penelitian.

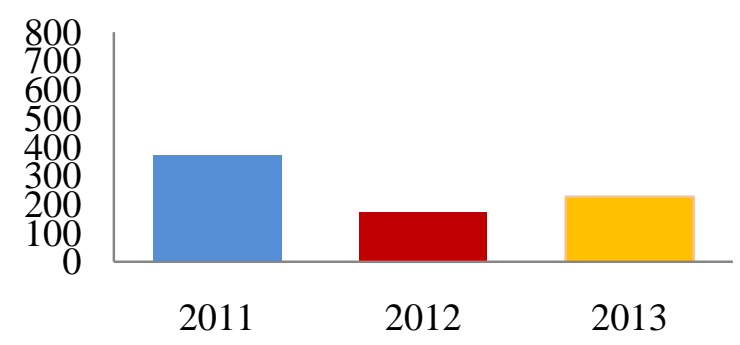

Gambar 1. Distribusi frekuensi responden yang menggunakan bahan tumpatan SIK berdasarkan tahun 2011-2013

Data pada Gambar 2 menggambarkan distribusi frekuensi responden yang menggunakan bahan tumpatan SIK berdasarkan jenis kelamin yang ditumpat di tahun 2011 hingga 2013. 
Tulaka, Wicaksono, Tumewu; Gambaran Penggunaan Semen Ionomer Kaca...

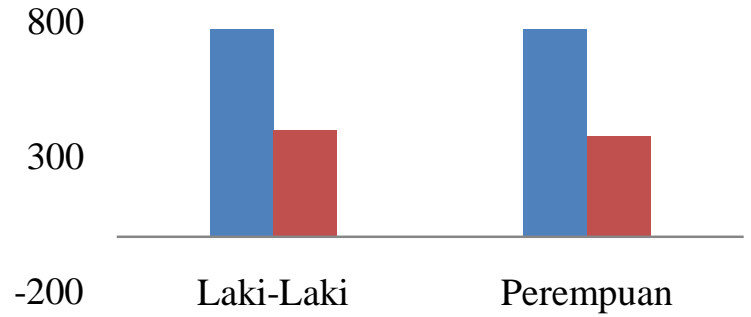

Gambar 2. Distribusi frekuensi responden yang menggunakan bahan tumpatan SIK berdasarkan jenis kelamin tahun 2011-2013

Data pada Gambar 2 menunjukkan bahwa pasien laki-laki lebih banyak menggunakan bahan tumpatan SIK dibandingkan pasien perempuan. Pada pasien laki-laki terdapat 394 gigi (51,3\%) yang ditumpat dengan menggunakan bahan SIK, sedangkan pada pasien perempuan terdapat sebanyak 375 gigi (48,7\%).

Data pada Gambar 3 menggambarkan distribusi frekuensi responden berdasarkan penggunaan bahan tumpatan SIK berdasarkan jenis kelamin di tahun 2011.

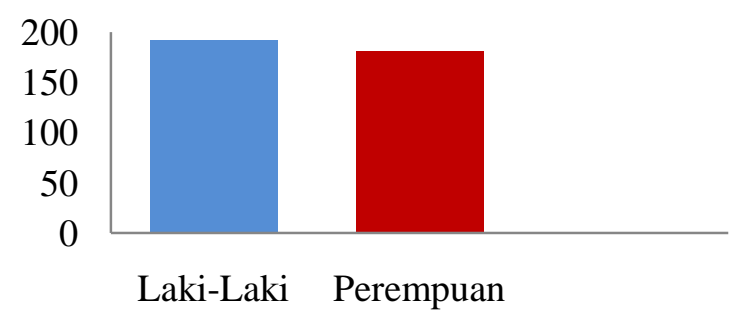

Gambar 3. Distribusi frekuensi responden yang menggunakan bahan tumpatan SIK berdasarkan jenis kelamin tahun 2011.

Distribusi responden berdasarkan jenis kelamin di tahun 2011 menunjukkan bahwa pasien laki-laki lebih banyak melakukan penumpatan dengan bahan tumpatan SIK dibandingkan pasien perempuan. Pada pasien laki-laki terdapat 191 gigi (51,3\%) yang menggunakan bahan tumpatan SIK, sedangkan pada pasien perempuan terdapat 181 gigi (48,7\%) yang menggunakan bahan tumpatan SIK.

Data pada Gambar 4 menggambarkan distribusi frekuensi responden yang menggunakan bahan tumpatan SIK berdasarkan jenis kelamin yang ditumpat di tahun 2012.

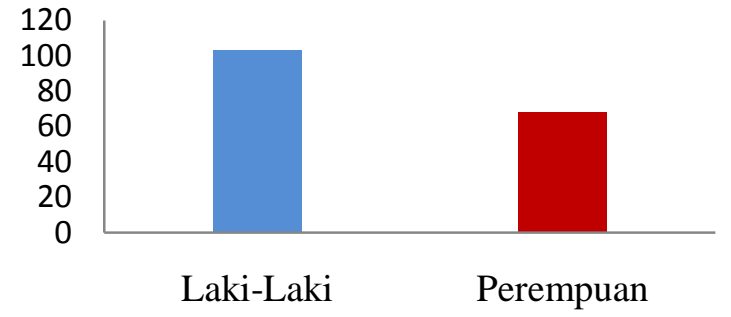

Gambar 4. Distribusi frekuensi responden yang menggunakan bahan tumpatan SIK berdasarkan jenis kelamin tahun 2012.

Distribusi responden berdasarkan jenis kelamin di tahun 2012 menunjukkan bahwa pasien laki-laki lebih banyak menggunakan bahan tumpatan SIK dibandingkan pasien perempuan. Pada pasien laki-laki terdapat 103 gigi $(60,2 \%)$ yang menggunakan bahan tumpatan SIK, sedangkan pada pasien perempuan terdapat sebanyak 68 gigi $(39,8 \%)$ yang menggunakan bahan tumpatan SIK.

Data pada Gambar 5 menggambarkan distribusi frekuensi responden yang menggunakan bahan tumpatan SIK berdasarkan jenis kelamin yang ditumpat di tahun 2013.

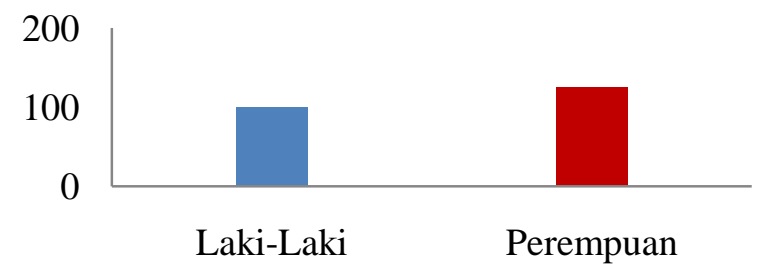

Gambar 5. Distribusi frekuensi responden yang menggunakan bahan tumpatan SIK berdasarkan jenis kelamin tahun 2013.

Distribusi responden berdasarkan jenis kelamin di tahun 2013 menunjukkan bahwa pasien perempuan lebih banyak melakukan penumpatan dibandingkan pasien laki-laki. Pada pasien perempuanterdapat 126 gigi (55.8\%) yang menggunakan bahan tumpatan SIK, sedangkan pada pasien laki-laki terdapat 100 gigi (44.2\%) yang menggunakan bahan tumpatan SIK.

Data pada Gambar 6 menggambarkan distribusi frekuensi responden yang menggunakan bahan tumpatan SIK berdasarkan usia yang ditumpat di tahun 2011-2013 


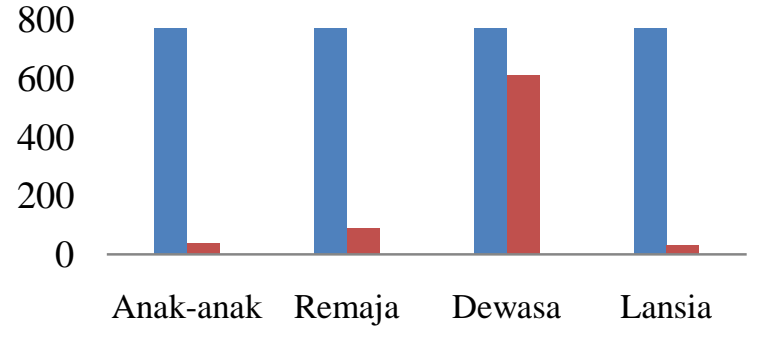

Gambar 6. Distribusi frekuensi responden yang menggunakan bahan tumpatan SIK berdasarkan usia tahun 2011-2013.

Distribusi responden berdasarkan kelompok usia di tahun 2011-2103 menunjukkan bahwa pasien dewasa (19-55 tahun) lebih banyak menggunakan tumpatan SIK yaitu sebanyak 609 gigi (79,2\%), untuk rentang usia remaja (13-18 tahun) sebanyak 89 gigi $(11,6 \%)$, untuk rentang usia anakanak (>12 tahun) sebanyak 40 gigi (5,2\%), dan untuk rentang usia lansia ( $<56$ tahun) sebanyak 31 gigi (4,0\%).

Data pada Diagram 10 menggambarkan distribusi frekuensi responden yang menggunakan bahan tumpatan SIK berdasarkan usia yang ditumpat di tahun 2011.

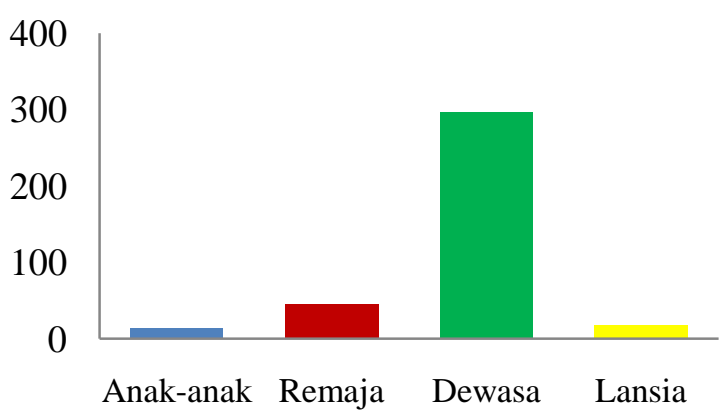

Gambar 7. Distribusi frekuensi respondenyang menggunakan bahan tumpatan SIK berdasarkan usia tahun 2011

Distribusi frekuensi responden berdasarkan kelompok usia di tahun 2011 menunjukkan bahwa pasien dewasa (19-55 tahun) lebih banyak menggunakan bahan tumpatan SIK yaitu sebanyak 296 gigi (79,6\%), untuk rentang usia remaja (13-18 tahun) sebanyak 45 gigi (12,1\%), untuk rentang usia lansia ( $>56$ tahun) sebanyak 18 gigi $(4,8 \%)$, dan untuk rentang usia anak-anak ( $<12$ tahun) sebanyak 13 gigi $(3,5 \%)$.
Data pada Diagram 8 menggambarkan distribusi frekuensi responden yang menggunakan bahan tumpatan SIK berdasarkan usia yang ditumpat di tahun 2012.

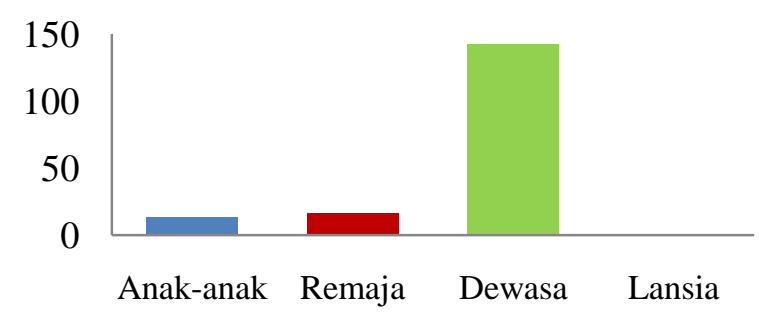

Gambar 8. Distribusi frekuensi responden yang menggunakan bahan tumpatan SIK berdasarkan usia pada tahun 2012.

Distribusi responden berdasarkan kelompok usia di tahun 2012 menunjukkan bahwa pasien dewasa (19-55 tahun) lebih banyak menggunakan bahan tumpatan SIK yaitu sebanyak 142 gigi (83,0\%), untuk rentang usia remaja (13-18 tahun) sebanyak 16 gigi $(9,4 \%)$, untuk rentang usia anakanak ( $<12$ tahun) sebanyak 13 gigi $(7,6 \%)$, sedangkan untuk rentang usia lansia ( $>56$ tahun) tidak ada yang melakukan penumpatan pada tahun 2012.

Data pada Diagram 9 menggambarkan distribusi frekuensi responden yang menggunakan bahan tumpatan SIK berdasarkan usia yang ditumpat di tahun 2013.

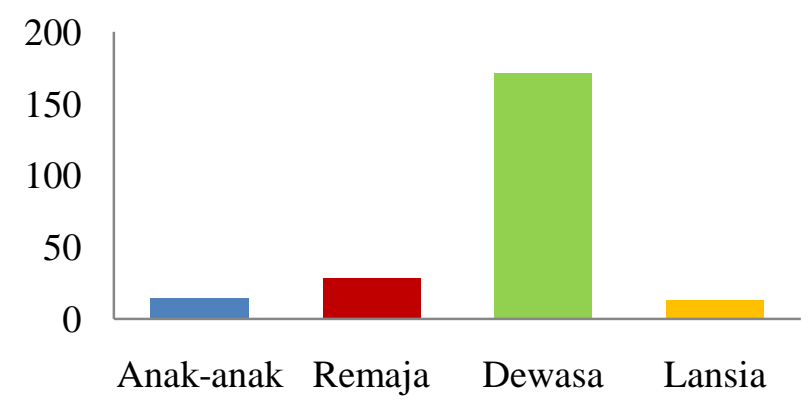

Gambar 9. Distribusi frekuensi respondenyang menggunakan bahan tumpatan SIK berdasarkan usia pada tahun 2013

Distribusi responden berdasarkan kelompok usia di tahun 2013 menunjukkan bahwa pasien dewasa (19-55 tahun) lebih banyak menggunakan bahan tumpatan SIK, 
Tulaka, Wicaksono, Tumewu; Gambaran Penggunaan Semen Ionomer Kaca...

yaitu sebanyak 171 gigi (75,7\%), untuk rentang usia remaja (13-18 tahun) sebanyak 28 gigi (12,4\%), untuk rentang usia anak-anak ( $<12$ tahun) sebanyak 14 gigi $(6,2 \%)$, sedangkan untuk rentang usia lansia ( $>56$ tahun), penggunaan bahan tumpatan SIK dilakukan pada 13 gigi (5,7\%) pada tahun 2013.

Data pada Diagram 10 menggambarkan distribusi frekuensi responden yang menggunakan bahan tumpatan SIK berdasarkan regio gigi yang ditumpat di tahun 20112013.

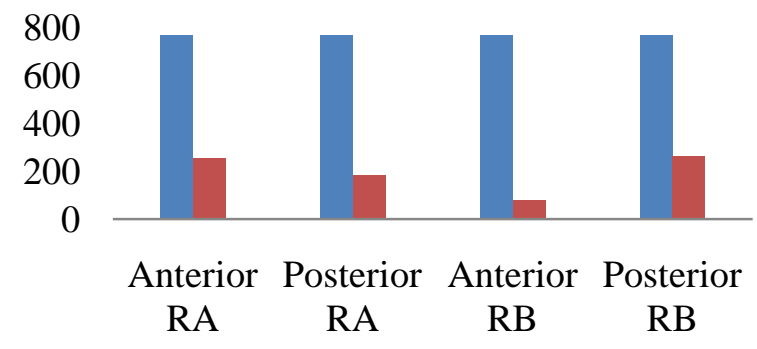

Gambar 10. Distribusi frekuensi responden yang menggunakan bahan tumpatan SIK berdasarkan regio gigi tahun 2011-2013

Data pada Gambar 10 menunjukkan bahwa gigi yang paling sering menggunakan bahan tumpatan SIK yakni gigi Posterior Rahang Bawah sebesar 33,8\%, kemudian gigi Anterior Rahang Atas sebesar 32,6\%, gigi Posterior Rahang Atas sebesar 23,5\% dan yang paling jarang dilakukan penumpatan di tahun 2011-2013 yaitu gigi Anterior Rahang Bawah sebesar 10\%.

Data pada Diagram 11 menggambarkan distribusi frekuensi responden yang menggunakan bahan tumpatan SIK berdasarkan regio gigi tahun 2011.

Data pada Gambar 11 menunjukkan bahwa gigi yang paling sering menggunakan bahan tumpatan SIK yakni gigi Posterior Rahang Bawah sebanyak 126 gigi (33,9\%), kemudian gigi Anterior Rahang Atas sebanyak 121 gigi (32,5\%), gigi Posterior Rahang Bawah sebesar Posterior Rahang Atas sebanyak 83 gigi (22,3\%) dan yang paling jarang menggunakan bahan tumpatan SIK tahun 2011 yakni gigi Anterior Rahang Bawah sebanyak 42 gigi $(11,2 \%)$.

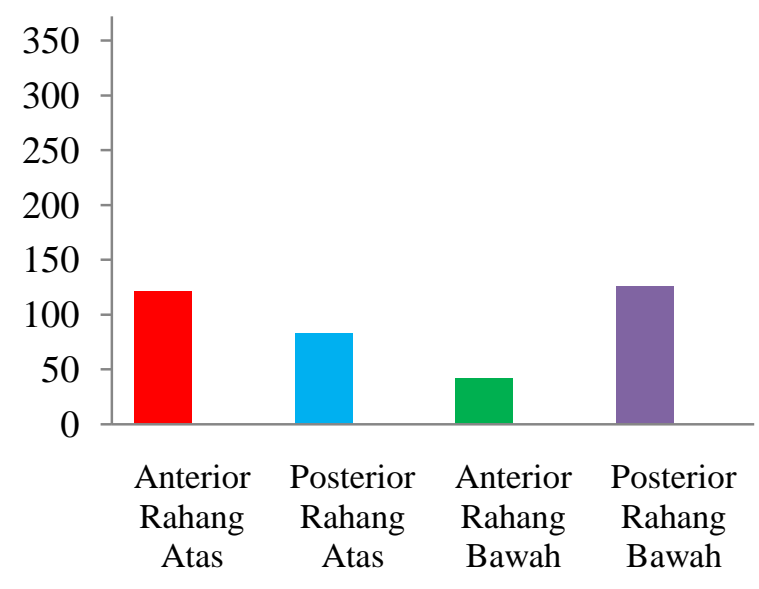

Gambar 11. Distribusi frekuensi responden yang menggunakan bahan tumpatan SIK berdasarkan regio gigi tahun 2011.

Data pada Gambar 12 menggambarkan distribusi frekuensi responden yang menggunakan bahan tumpatan SIK berdasarkan regio gigi yang ditumpat di tahun 2012 .

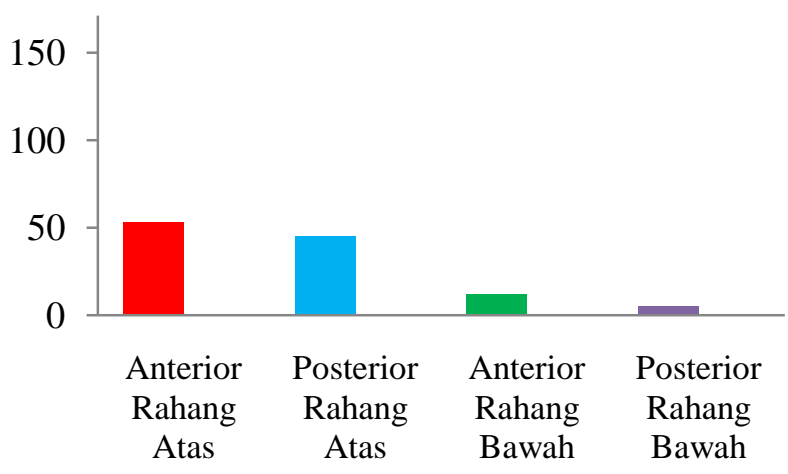

Gambar 12. Distribusi frekuensi responden yang menggunakan bahan tumpatan SIK berdasarkan berdasarkan regio gigi tahun 2012 .

Data pada Diagram 12 menunjukkan bahwa gigi yang paling sering menggunakan bahan tumpatan SIK yakni gigi Posterior Rahang Bawah sebanyak 61 gigi (35,7\%), kemudian gigi Anterior Rahang Atas sebanyak 53 gigi (31\%), Posterior Rahang Atas sebanyak 45 gigi (26,3\%). dan pada tahun 2012 gigi Anterior Rahang paling sedikit melakukan penumpatan SIK sebanyak 12 gigi (7)\%.

Data pada Diagram 13 menggambarkan distribusi frekuensi responden yang meng- 
gunakan bahan tumpatan SIK berdasarkan regio gigi yang ditumpat di tahun 2013.

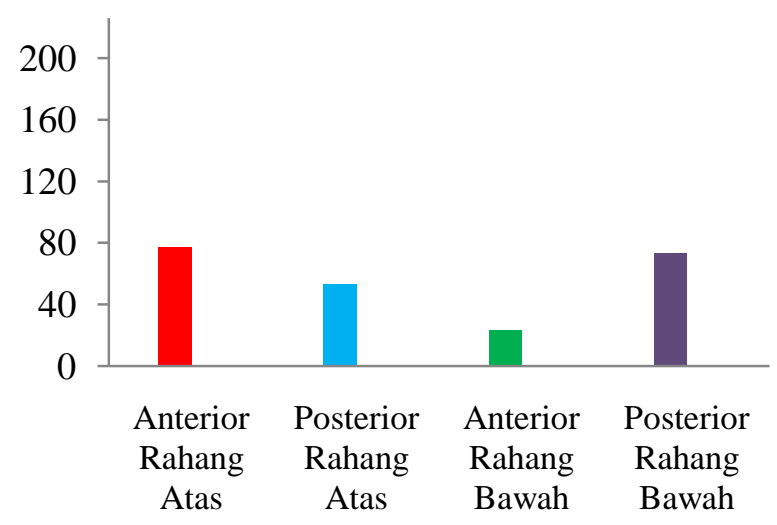

Gambar 13. Distribusi frekuensi responden yang menggunakan bahan tumpatan SIK berdasarkan regio gigi tahun 2013.

Data pada Diagram 13 menunjukkan bahwa gigi yang paling sering menggunakan bahan tumpatan SIK yakni gigi Anterior Rahang Atas sebanyak 77 gigi (34,1\%), Posterior Rahang Bawah sebanyak 73 gigi (32,3\%), Posterior Rahang Atas sebanyak 53 gigi $(23,5 \%)$ dan yang paling jarang menggunakan bahan tumpatan SIK yakni gigi Anterior Rahang Bawah sebanyak 23 gigi $(10,2 \%)$.

\section{BAHASAN}

Berdasarkan hasil penelitian yang dilakukan, diperoleh hasil bahwa penggunaan bahan tumpatan SIK pada tahun 2011 lebih tinggi jumlahnya dibandingkan jumlah penumpatan di tahun 2012 dan di tahun 2013. Dari data yang tercatat pada poliklinik gigi di RS R.W Mongisidi Manado diperoleh gambaran bahwa penggunaan SIK pada tahun 2011 ke tahun 2013 mengalami penurunan. Penyebab menurunnya pasien yang melakukan penumpatan bahan tumpat SIK mungkin dikarenakan berkurangnya prevalensi karies akibat pengetahuan masyarakat tentang pemeliharaan kesehatan gigi dan mulut yang meningkat. Hal ini disebabkan mayoritas pasien RS R.W Mongisidi ialah anggota TNI-AD. Sebagai anggota TNI-AD mereka telah memiliki jadwal pemeriksaan secara rutin, demikian halnya dengan informasi kesehatan yang diterima. Keadaan ini turut memengaruhi tingkat pengetahuan dan kesadaran mereka akan pentingnya menjaga kebersihan gigi dan mulut.

Banyaknya jumlah peenggunaan SIK mungkin juga disebabkan karena bahan tumpatan yang tidak sewarna dengan gigi seperti amalgam, sehingga penggunaannya menurun.Bahan tumpatan amalgam yang berwarna perak secara estetik kurang menarik, di samping itu bahan tumpatan amalgam mengandung merkuri yang berbahaya bagi kesehatan. Makin meningkatnya tuntutan terhadap segi estetik dan keamanan pasien dapat meningkatkan jumlah pemakaian bahan tumpatan SIK sebagai bahan tumpatan alternatif yang lebih menguntungkan. ${ }^{6}$

Berdasarkan hasil penelitian diperoleh data bahwa pada tahun 2011 kelompok pasien laki-laki yang menggunakan SIK sebagai bahan tumpatan lebih banyak dibandingkan dengan kelompok pasien perempuan. Pada tahun 2012 yang paling banyak melakukan tumpatan terdapat pada kelompok pasien laki-laki, sedangkan pada tahun 2013 yang paling banyak melakukan tumpatan dengan bahan SIK yaitu pada kelompok pasien perempuan. Dari data di atas dapat diketahui bahwa dari tahun 2011 sampai tahun 2013, paling banyak melakukan tumpatan SIK yaitu pada kelompok laki-laki, namun hasilnya tidak terlalu berbeda jauh.

Hasil penelitian ini tidak terlalu berbeda jauh antara laki-laki dan perempuan dikarenakan mayoritas yang melakukan penumpatan pada RS R.W Mongisidi Manado yaitu para anggota TNI-AD yang umumnya berjenis kelamin laki-laki.Adanya peningkatan kesadaran diri terhadap nilai estetika dan kebersihan diri pada laki-laki dewasa ini juga turut memegang andil dalam hasil penelitian yang dilakukan.

Berdasarkan distribusi data hasil penelitian menurut kelompok usia di tahun 2011 hingga 2013, yang paling banyak dilakukan penumpatan SIK yakni pada kelompok usia dewasa. Faktor usia 
seringkali berhubungan dengan tingkat kesadaran akan pentingnya kebersihan gigi dan mulut. Hasil penelitian ini serupa dengan penelitian yang dilakukan di poli gigi RS Gunung Maria Tomohon, dimana pasien dewasa lebih banyak melakukan penumpatan SIK dibandingkan kategori usia anak-anak, remaja dan lansia. ${ }^{7}$ Pada kelompok usia dewasa tingkat pengetahuan dan kesadaran diri terhadap nilai estetika dan fungsi gigi dalam mulut lebih tinggi dibandingkan dengan kelompok usia lainnya. ${ }^{8}$ Pada masyarakat kelompok usia anak-anak dan remaja biasanya kurang memerhatikan kebersihan gigi dan mulutnya. Masyarakat pada kelompok usia ini cenderung kurang memerhatikan keadaan giginya yang rusak akibat karies, demikian halnya pada kelompok usia lansia penumpatan juga sudah jarang dilakukan. Umumnya mereka lebih memilih untuk mencabut giginya apabila bermasalah dan menggunakan gigi tiruan dibandingkan melakukan perawatan dan dilanjutkan dengan penumpatan.

Dari hasil penelitian ini dapat diketahui bahwa penggunaan bahan tumpatan SIK tidak hanya digunakan pada gigi anterior tetapi juga pada gigi posterior. Berdasarkan distribusi data menurut elemen gigi di tahun 2011 hingga 2012, gigi yang paling banyak menggunakan bahan tumpatan SIK yakni gigi Posterior Rahang Bawah dan hasilnya berbeda dengan data tahun 2013, dimana gigi yang paling banyak menggunakan bahan tumpatan SIK yakni gigi Anterior Rahang Atas. Berdasarkan data tersebut diperoleh hasil bahwa selama tahun 2011 sampai 2013, gigi yang paling Sering menggunakan bahan tumpatan SIK yakni gigi Posterior Rahang Bawah. Hasil penelitian ini serupa dengan penelitian yang dilakukan di poli gigi RS Gunung Maria Tomohon dimana gigi Posterior Rahang Bawah sering melakukan penumpatan. ${ }^{7}$ Pada gigi posterior sering dilakukan penumpatan dikarenakan mungkin dikarenakan gigi posterior terutama gigi molar rahang bawah merupakan gigi permanen yang relatif lebih dulu erupsi dibandingkan gigi lainnya. Hal ini menyebabkan gigi molar rahang bawah memiliki risiko yang lebih tinggai terhadap kerusakan dibandingkan gigi lainnya.Di samping itu gigi bagian posterior menerima beban kunyah yang paling besar karena hampir setiap saat gigi-gigi ini digunakan untuk mengunyah makanan. Adanya pit dan fissure yang cukup banyak pada anatomi gigi bagian posterior terutama di gigi molar, memudahkan terjadinya retensi makanan dan merupakan tempat ideal bagi pertumbuhan bakteri yang dapat menyebabkan karies. Terdapat kesulitan untuk membersihkan dengan baik pada daerah pit dan fissure gigi molar memakai sikat gigi, karena sebagian besar bagian dalam pit dan fissure tidak dapat dicapai dengan bulu sikat gigi sehingga menjadi salah satu penyebab gigi molar mudah terkena karies dibandingkan gigi lainnya., Gigi Anterior pada bagian proksimal juga sering terkena karies karena adanya sisa-sisa makanan yang tertinggal yang bersamasama dengan kuman dalam mulut sehingga membentuk plak. Plak yang terakumulasi pada permukaan gigi dalam waktu tertentu memiliki potensi merusak email gigi. Keberadaan gigi anterior yang mudah dilihat antara lain juga turut memengaruhi banyaknya gigi anterior yang ditumpat. Adanya kerusakan yang kecil namun terlihat, merupakan salah satu alasan untuk dilakukannya penumpatan pada gigi anterior. Gigi anterior juga sangat penting dalam menunjang penampilan seseorang. Kepedulian instansi RS R.W Mongisidi terhadap anggota TNI-AD untuk merawat kesehatan gigi dan mulut dapat meningkatkan rasa percaya diri para anggota.

\section{SIMPULAN}

Penggunaan bahan tumpatan SIK pada tahun 2011 lebih tinggi dibandingkan pada tahun 2012 dan tahun 2013.Penggunaan bahan tumpatan SIK tidak jauh berbeda jumlahnya antara pasien laki-laki dan perempuan.Penggunaan bahan tumpatan SIK lebih banyak digunakan pada pasien dewasa. Elemen gigi yang paling banyak menggunakan bahan tumpatan SIK yaitu gigi Posterior Rahang Bawah. 


\section{SARAN}

Diharapkan data hasil penelitian dapat digunakan oleh instansi kesehatan terkait dalam hal ini RS R.W. Mongisidi dalam perencanaan untuk meningkatkan pelayanan kesehatan gigi kepada pengunjung rumah sakit.Perlunya dilakukan penelitian lanjutan berkaitan dengan penggunaan bahan tumpatan SIK guna memperoleh informasi tentang ketahanan bahan tumpatan ini dalam hubungannya dengan waktu, kemampuan bertahan terhadap tekanan dan kemampuan berikatan dengan elemen gigi yang ditumpat.

\section{DAFTAR PUSTAKA}

1. Agtini M. Efektivitas pencegahan karies dengan atraumatic restorative treatment dan tumpatan gelas dan tumpatan gelas ionomer cement dalam pengendalian karies di beberapa negara. Media Litbang Kesehatan. 2010;20(1): h.1

2. Kidd E, Bechal S. Dasar-dasar karies penyakit dan penanggulangannya. Cetakan II. Jakarta : EGC. 2012; h.1
3. Fauziah E, Suwelo I, Soenawan H. Kandungan unsur fluorida pada email gigi tetap muda yang ditumpat semen ionomer kaca dan kompomer. Indonesian Journal of Dentistry. 2008;15(3): h. 205-11

4. Nagaraja P, Kishore G. Glass ionomer cement-the different generations. Trends Biomater Artif Organs. 2005;18(2):p.158

5. Yanti N. Restorasi sandwich semen ionomer kaca dengan resin komposit. e-USU Repository. 2004; h.2

6. Indriani. Survey pemaparan penggunaan amalgam, GIC dan resin komposit sebagai bahan tumpat gigi di RSGMP FKG UI pada tahun 2005, 2006 dan 2007. Fakultas Kedokteran Gigi Universitas Indonesia; 2008

7. Michael S. Gambaran penggunaan resin komposit dan semen ionomer kaca sebagai bahan restorasi di poli gigi Rumah Sakit Gunung Maria Tomohon tahun 2012. Skripsi. Manado: PSKG UNSRAT 2013

8. Locker D, Jokovic A, Kay EJ. Prevention. Part 8: The use of pit and fissure sealants in preventing caries in the permanent dentition of children. Briths J Dent. 2003;195:375-8. 